$621.891: 531.44$

\title{
摩擦之表面あ らざ
}

\section{1.まえがき}

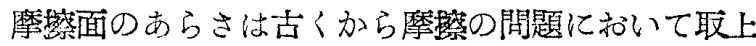
げられて打り，摩擦研究の初期に打いて Amontons や Coulombら溒面の凹凹によって摩掽の機棈を説明し ている・かれらは摩摖部分を佣体と考えたのであるう

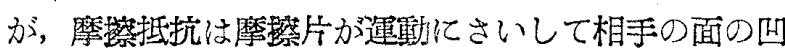
凸を上下するために生ずるのだと考えた。これは摩檫 機榡のモデルとしてきわめて考えやすいのであるが， その後凹山説の不都合な点务澌らかとなり，Hardy ${ }^{(1)}$, $\mathrm{Holm}^{(2)}$ および Bowden ${ }^{(3)}$ らによって 摩攃の 凝聙説 が屋開されてきた。凝着説は，摩㻮面の真実接触点間 に速続的な金属結合が扣てると考えて，摩擦抵抗はこ の金属結合をせん断ずるために生ずると考えるのであ

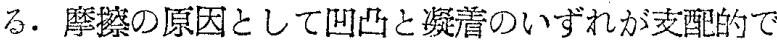

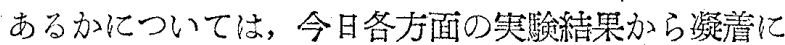
よるものが大部分であるとと加確かめられている・し かし表面の凹凹加摩綮の主な原区となりえないとして も，摩穄面のあらさが乾懆摩撚和よび㜔界摩擦に扣い

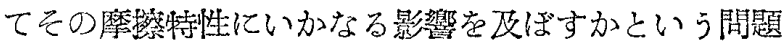
はあまり明らかにされていないようである・境界潤滑 に和けるあらさの間題について Bristow ${ }^{(4)}$ か実跧を 行った程度である・あらさと摩擦の関係は実際閒題に おいても関心をもたれる間題であるが，さらに摩摖の 機構とも関連して検討してみる必要がある。この研究 は乾燥摩撚扣よび境界摩擦に及ぼす摩擦面のあらさの 影響岂明らかにすることを企図したものである。

\section{2. 実 験 方 法}

この觅験は運動摩撚係数を測定したものであって， 静止摩摖係数は求めていない.摩摖力の湘定にばstickslip 摩㨙測定装置を用いた。

使用した試験片には，下部は軟鎦摩摖友，上部は直 径 $4 \mathrm{~mm}$, 先端球面状の各種全属の 摩擦棒 扣よび直堡 3/16” の軸受用鋁球を用いた。軟釦摩摖板の表面あら さを 8 種類に変化し，その加工方法としてはラップ仕 上，ペーパ任上を用いた。第 1 図は小坂式触針あらさ

* 隍稿受付 昭和 29 年 10 月 6 日

*** 姃員, 東京大学理工学研究所。
宮川行 雄**

䛨で測定した加工方向に直角，平行方向のあらさ曲䠌 を示したものである.第1表敒 1 第から求めたあら さの最大值扣よび加工方向值直な方向に打ける凹起 の底庙を示してある。

摩攃面の洗浄には電解洗浄法を用いてできるだけ清 浄な面をうるようにした。

摩摖試験条件としては荷重は全部 $1 \mathrm{~kg}$ ，すべり速度 は $0^{\circ} 05,0.5,5 \mathrm{~mm} / \mathrm{s} の 3$ 種である。

\section{3. 乾笨摩擦の実験結果}

第 2,3,4 困に 3 種類の金属について運動摩擦係数 とあらさの関係を示す．橫軸は表面あらさの符号で右 のちほどあらさか増大している。

第 2 図は銅/颤鈰板の場合で, 銅の表面あらさは初め の面が摩摖によって藷しく摩耗し内部の金属があらわ れるため影響しない，C抽よび C'のあらさで摩擦は 最小值を示し，てれより面があらくなるにしたがって

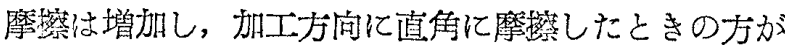
平行方淌に扣けるよりも摩擦係数，摩摖の增加量が大 きい，C执よび $\mathrm{C}^{\prime}$ 以下のあらさでもかえって摩擦の 增加するのがみられる。

第 3 困は黄銅/軟鋼板の結果で, 黃銅面のあらさは初 めの面が摩耗するので影響しない，摩擦板のあらいほ

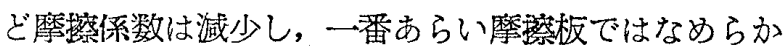
な面の約 $60 \%$ の摩摖係数を示している. 摩摺方向の 影響はみられず，加工方向に平行に摩攃したときの方 がむしろ摩擦の大きい場合もみられる。すべり速度の 大きいほど摩擦低下が大きい。

第 4 圀は鋼球/軟鋼板の結果で，4 種類のあらさの鋼 球について摩撜板のあらさの影蠁を示したものであ る.鋼球面の岕らさは $\mathrm{A}, \mathrm{D}, \mathrm{F}$ ○ 3 種と， $\mathrm{A} / \mathrm{A}, \mathrm{B} / \mathrm{B}$ というように各摩摖板のあらさと刘応させたものであ る.すべり速度は $0.05 \mathrm{~mm} / \mathrm{s}$ の場合のみを示した。

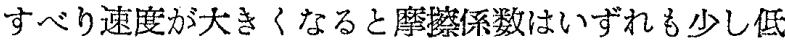
下している，表面あらさの㭔擦特性に扣よぼす影響と しては，加工方向に直看に摩擦した場合には一定のあ らさの銅球面に対しては，摩擦板のあらいほど摩擦係 数低低々，一定のあらさの摩擦板に対しては銅球面の あらいほど摩攃係数は大きい。両摩擦面の苟らさが䞑 
80 宫师雄

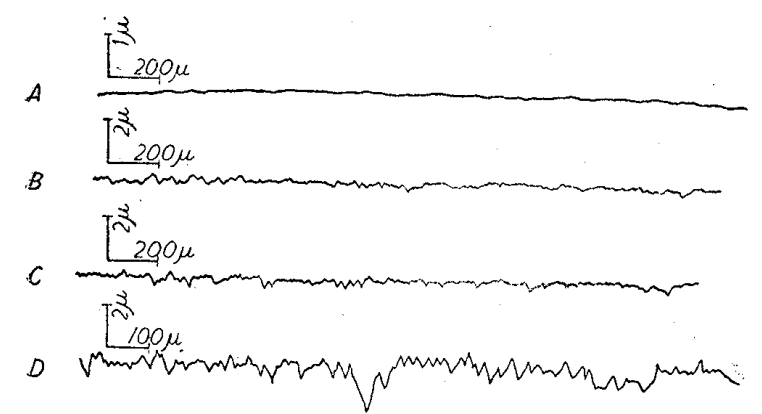

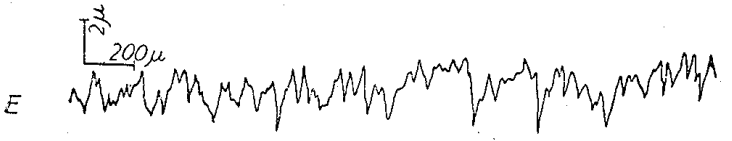

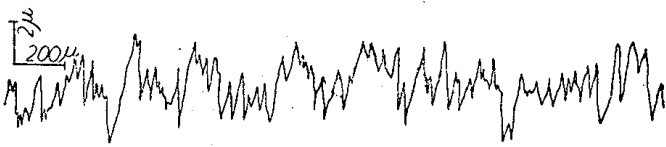
$\pi a^{3}$

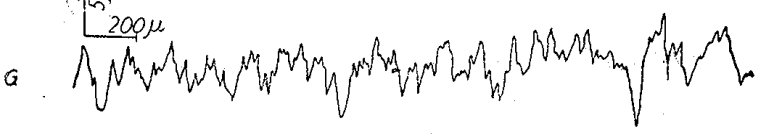

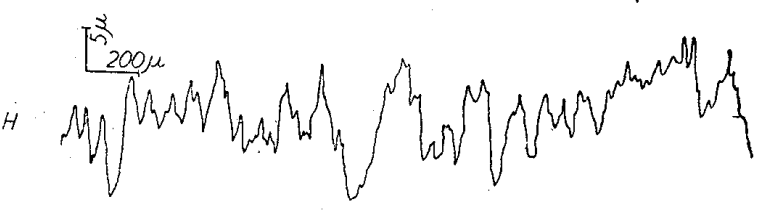
(a) 扣工方向比直角 第 1 表

\begin{tabular}{|c|c|c|c|c|c|}
\hline \multirow{2}{*}{ 加工方法 } & \multicolumn{3}{|c|}{ 加工方向に㨁偖 } & \multicolumn{2}{|c|}{ 加工方向火本行 } \\
\hline & 符量 & 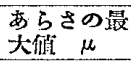 & 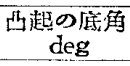 & 符量 & $\begin{array}{l}\text { あらさの最 } \\
\text { 大䛧 }\end{array}$ \\
\hline ラップ仕上 & A & $<0.1$ & & $A^{\prime}$ & $<0 \cdot 1$ \\
\hline ペーパ仕上 & B & 0.3 & $<2$ & $B^{\prime}$ & 0.2 \\
\hline " & C & 0.6 & $<2$ & $\mathrm{C}^{\prime}$ & 0.4 \\
\hline$"$ & $\mathrm{D}$ & $1 \cdot 3$ & $2-3$ & $D^{\prime}$ & 0.8 \\
\hline " & $\mathrm{E}$ & 3 & $3 \sim 4$ & $E^{\prime}$ & 12 \\
\hline$"$ & $\mathrm{~F}$ & 5 & $4 \sim 5$ & $F^{\prime}$ & $1 \cdot 7$ \\
\hline$"$ & G & 9 & $6 \sim 7$ & $G^{\prime}$ & 7 \\
\hline " & $\mathrm{H}$ & 15 & $10 \sim 11$ & $\mathrm{H}^{\prime}$ & 10 \\
\hline
\end{tabular}

応しているときはF以上のあらさで摩擦增加がみられ るが，最すあらい H/H の組合せ亿扣いてもなめらか な面同誌の摩撚係数と同じにすぎない. 加工力问に平

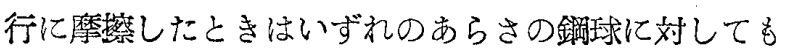
摩撚板のあらいほど摩攃係数は小さく，一定のあらさ の摩㪇板に対しては鍓球面のあらいほど摩擦は大きい がその割合はきわめて小さい。

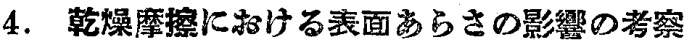

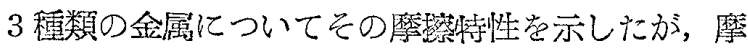
擦面のあらいほど一般に摩摖は大きいと考えられる が，逆に摩攃の低下する場合もみられ，複雑な特性党

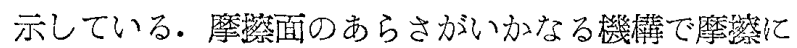
影響を与えるかを垫察することにする。

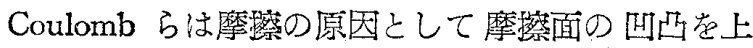
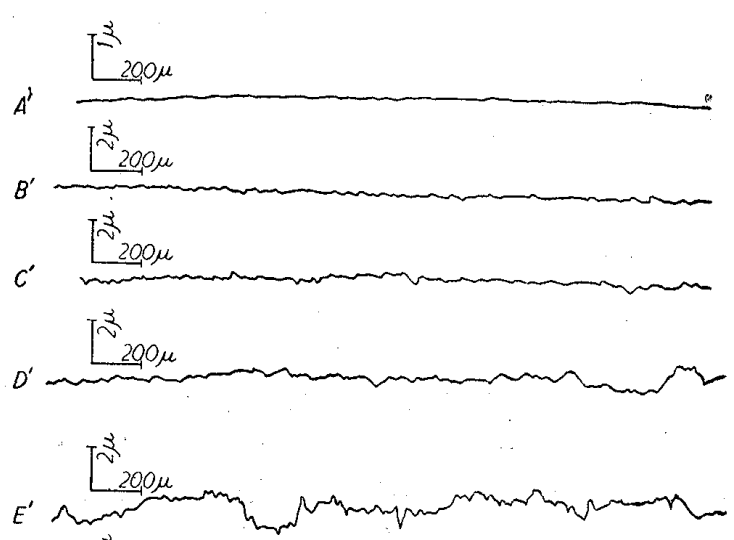

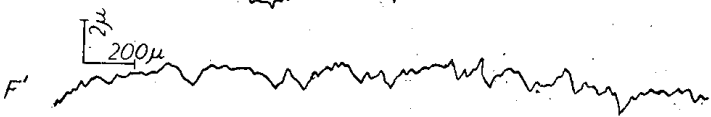

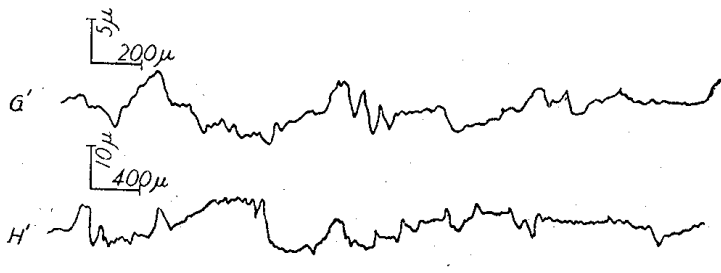

(b) 加工方䛔に车行
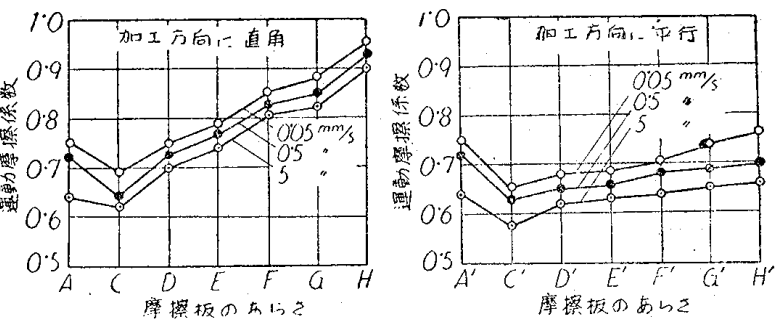

第 2 园銅/軟部板
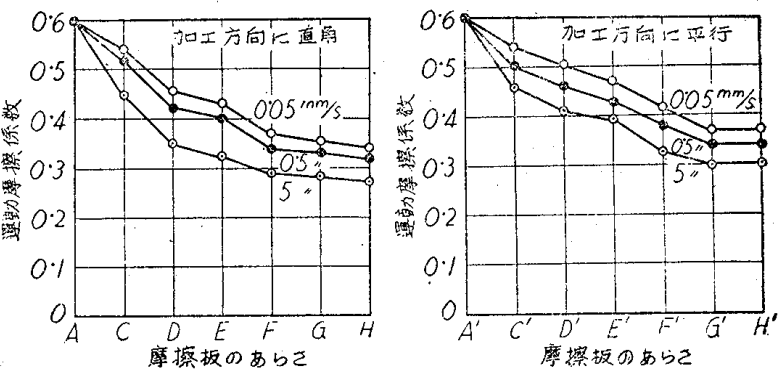

第3図黄銅／軟銅板
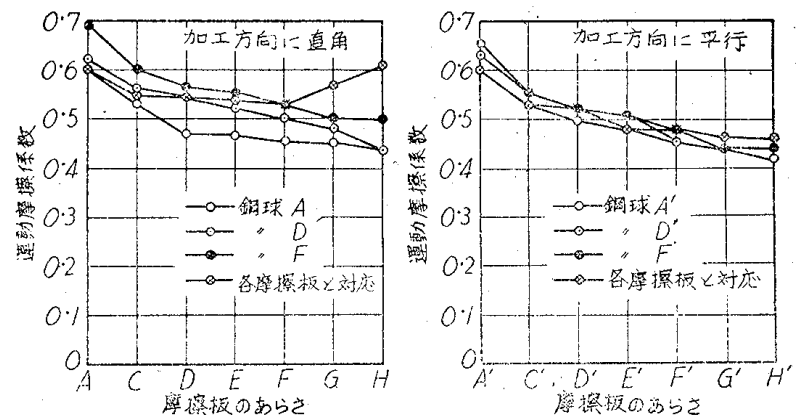

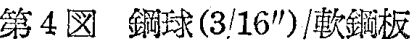


下するための抵抗を考えたのであるが，摩䑢されたさ い摩摖面の四凹が原形のまま保持されるが疑問で 西る。きわめて軽荷重に扣いても，Whitehead(5) が 電子顥微鏡で期らかにしてあるでとく，荷重の大きい 埸合と本質的に全く同じ摩擦面のきずあとを示して打 り，摩摖を単に表面的に考えるととは閏題である. と

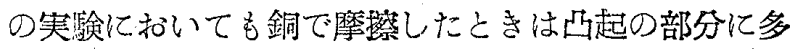
量の銅の附着がみられ切削的な現象を示し，銅球の場 合は瑱鋼板の凸起上部が扣しつぶされて扔り，表面の

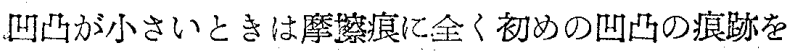
残していない，摩摖特性沉扔いても，鋼球/軟銅, 黄銅/

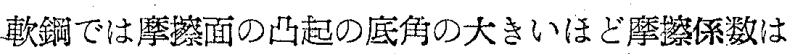
小さく，銅/軟銅できなめらかな面で大きい摩摖を示し ている、叫凸を上下すると考えたときの平均運動摩撚 係数仙訐算上 $1 / 2 \cdot \tan \theta(\theta$ 纹凸起の底角) で，底角の 大きいほど摩摖係数は大きくなり，なめらかな面では 摩擦が非営に小さいてとになる。乙れは实験結果と相

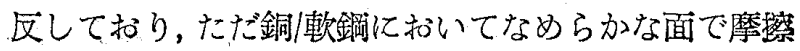
の大きいととを除けば摩摖俰数は凸起の底角が大きく なるほど增えている。とのととは山凸説による特性と 一致しているが、凹 起の底觔引平均運 辞摩嚓係数を求めて 比競してみよう。第 2 表に加工方向に亩 角に摩擦したときの 前述の式加方求めた

第 2 表

\begin{tabular}{|c|c|c|c|}
\hline \multicolumn{4}{|c|}{ 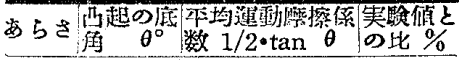 } \\
\hline D & $2-3$ & $0^{\circ} 022$ & $2 \cdot 9$ \\
\hline $\mathrm{E}$ & $3 \sim 4$ & 31 & $3 \cdot 9$ \\
\hline$F$ & $4-5$ & 0.039 & $4^{\circ} 6$ \\
\hline G & $6 \sim 7$ & 57 & 6.5 \\
\hline $\mathrm{H}$ & $10 \sim 11$ & $0^{\circ} 093$ & 9.8 \\
\hline
\end{tabular}

平均運㗢摩擦係数扣よび実験值との比を示す. 凹凸説 加ら求めた平均運動摩摖係数はきわ妃さく，あら い摩燃面で全摩摖抵抗の3〜10\%にすざないてとがわ 功る. との結果は Lewis 打よび Strang(6) の結果と よく一致しているたただし呵凸を考えるさいE視的な 四凹とともに接俜面に扣ける微視的な山凹についても

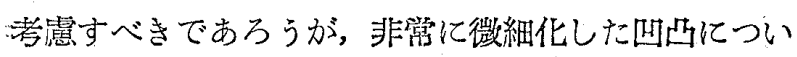
てその傾斜面を上下するという考え方がそのまま通用 するかどうかは疑問である。

表面の凹凸を上下するための損失は摩摖任事のわず かな部分を占めるにすざないととがわかり，摩摖の主 な原因としては接触面の㠜請によると考えるのが自然 なようである、真実接触面に打ける㠜着を考えたとき， 表面あらさは摩嚓抵抗にいかなる影響を捛よばすであ

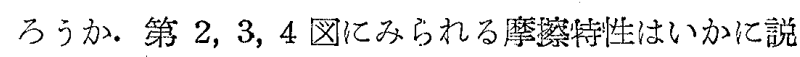
明されるか検討することにする，摩撚抵抗として四凹 を上下するための抵抗以外にしては，真実接触面に生 じた凝着部の金属結合をせん断するための抵抗，摩祭 痕として变形や掘り扣てし觉与える抵抗方主なるのと
して考えられる。㠜着による抵抗は真実接触面積をA， やわらかい方の材料のせん断強さを $s$ とすれば $A \cdot s$ で，掘り打てし抵抗を $F_{p}$ とすれれば主要な魔祭抵抗は 次式で示される.

$$
F=A \cdot s+F_{p}
$$

凹山を上下するための抵抗がてれに加わるわけである が，上述のでとく摩擦抵抗のでく一部にすぎない、し たがっって表面の山出方摩擦におよばす影響はあらさの $A \cdot s$ 扣よび $F_{p}$ 亿与える変化となる.

真実接触面積と表面あらさの関係仙ついて考察して みよう。真実峖触面に扔いて压力が材料の降伏点に達

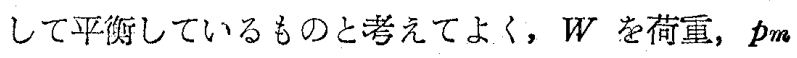
を降伏応力としたとき，

$$
A=W / p_{m}
$$

となる. $p_{m}$ は $Y$ を弾性限度, $C$ を係数とすれば

$$
p_{m}=C Y
$$

で示される.

かたい金属の山起がやわらかい金属平面と接触した とき凹起の形状を円すいとすれば， $C$ は円すいの頂角 によって変化し, Bishop, Hill 拀よび Mott ${ }^{(7)}$ によれ ば鋼円すいと銅のとき頂角 $180^{\circ}$ で約 3 で，頂看の減 少とともに增加する．ただし摩摖面にある凹山の焦度 範用ではほぼ一定と見なしうるＹ江頂角の小さいほ ど加工嗖化が大きく增加する。したがって凸起の鋭い ほど p $m$ は大きくなるから真先接触面積は減少する. かたい金属平面とやわらかい金属の円すい状山起と接

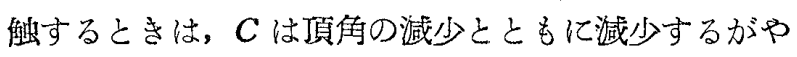
はり摩搖面の凹山の角度範团ではほぼー定と見なしう る. $Y$ については山起の鋭いほど加工硬化が大きく増 えることになる。したがって凹起の鋭いほど真実接触 面積は減少する。，耐面に四凹がある場合にう同様な結 喿が考光られる・しかし凸起の筒展と同時に凸起の高

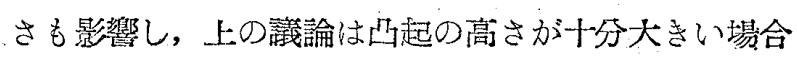
で，もしも凹起の高さが非常に小さくやわらかい金属 か河凸を埋めつくすとか，やわらかい凹起方完全に扣 しつぶされるときには，真実接触面積は四凸にほとん ど無関係といえる・したがってれ起の角度之高さを合 せて考元齐ばならないが，ての笑験に供したあらさ面 に扔いては凹起の鋭いほど高さも大きくなっているか ら，ての場合真実接触面積淔のあらいほど減少する と荐えられる。もち万ん運動中心は他の影響も入り簡 単にはいえないと思うが、だいたいの傾向としては減 少すると考えてよいであるう。

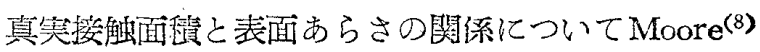

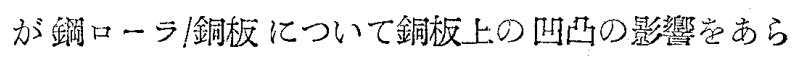

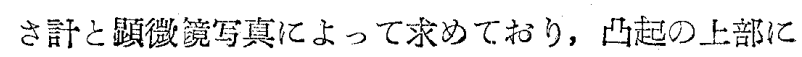


打ける接触面積はなめらかな面に叔ける接触面積の 1/2〜2/3 となっている. 電気抵抗から求めたあらさの 影響としては，曾田，深谷両氏(9)は真笑接触面積は表 面あらさとほとんど無関係であるという結果を洴して おりり, Holm(10) はあらい面では電気抵抗がわずかに增 加するとのべている.いずれもあらさの形状などにつ いて住触れていないが，さきに述べたようにあらさの 小さいときは，影留はほとんど無いというととは考光 られるが，電気抵抗から真実接触面積を求めるととに は非常に難点がある. 電気抾抗法で接蚛面積を求める 祭に接触点の分布の間題がからんでくるためである。

せん断強さ $s$ の変化としては, 面があらい注ど上述 のごとく加工硬化の影響が大きく真実接触圧力も大き いから，高圧のもとでは坞ん断虽さが大きくなるとい

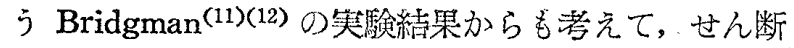
強さは真実接触压力に比例儿て大きくなると考えられ る・したがって表面のあらさの増大とともに真笑接触 面積 $A$ は娍少するが，せん断強さ $s$ は大さなるから 凝着担挖 $A \cdot s$ はほぼあらさに無関係に一定と考光ら れる. Holm ${ }^{(13)}$ は摩擦力を真笑接娟面積で㫼った比摩 瑟力で摩攃の解析を行っている.この比摩䅎力はせん 断㧧さに相当するもので，真箺接触面が完全に凝着し て一体化して扣ればせん断強さと同等になるべきもの である・かれの实験結果によれば比摩撜力はせん断強 さよりも小さいが，てれは摩擦面に捛ける必然的なよ ごれの存在から当然であるが，此摩㩯力络真実接触圧 力に無関係に葟ば一定となっている. Bowden ${ }^{(4)}$ の In についての比摩擦力は, Inの材料試験によるせん断強 さよりも大きくなっている・材料試験機による強さよ りも犬きいのは当然で, 加工硬化, 高压による增加も あると思うが真芙接触圧力との関係はつかめない。乙 の点について現状では不明確なととはいたしかたのな いとてろで，だいたいの㑯向としてせん断強さは真実 接蚛生力の増加によって增大するか一定と考えてよい であ万う・したがって凝着抵抗はあらさにほぼ無関係 であるか，もしくはあらさの増大とともに減少する傾 向があると考えてよいであろう。

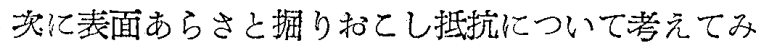
る.掘り扣てし抵抗は実際の摩擦面に扣いて他の摩攃 担抗と分離して考えにくいものであるが，きわめて簡 単な乏デルについてその㑯向をしらべることにする。

かたい金属の山面とやわらかい金属面方揬触して

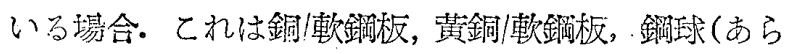

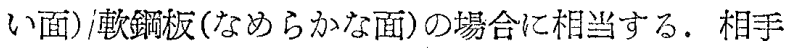
金属方あまりかたくなると四出自身の变形も生じてく る. 表面の川起簡监化し可すいと敒定し，接触面内
の山起の数すなわち接触点を $n$ とする・一つの凸起に よって与えられる摩整痕の演を $d$, 山起の頂角を $\alpha$ と すれば，摩擦痕の橫断面積は $d^{2} / 4 \cdot \cot \alpha / 2$ となる. やわらかい金属を排除するために要する平均压力は接 触面生力に比例すると考えられるから，全体の掘り标 こし抵抗は

$F_{p} \propto n \cdot d^{2} / 4 \cdot \cot \alpha / 2 \cdot p_{m}$
となる・摩鿟痕の幅 $d$ は
$d \propto 1 /\left(n p_{m}\right)^{\frac{1}{2}}$

であるから結局 $F p$ は炏式で示される.

$$
F_{p} \propto \cot \alpha / 2
$$

したがって掘りおてし抵抗は $\alpha$ 小さいほどすなわち ム起の鋭いほど増加する。

かたい金属面とやわらかい金属の凹山が接触してい る場合こてれは鋼球(なめらかな面)/軟鋼板(あらい面) に相当する：山起を円すいと仮定し同様にして，

$F_{p} \propto n d^{3} i a \cdot \cot \alpha / 2 \cdot p_{m}$

こてに は山起聞の距離である. $n \infty 1 l a$ と考えれば

$$
F_{p} \propto 1 /(a p m)^{\frac{1}{2}} \cdot \cot \alpha / 2
$$

したがってら起が鋭く，ピッチの大きいはど（これは $p_{m}$ の増加を伴う）掘り拝しし抵抗は隇少する。前に 述べたようにての実験に供した面ではあらさの大きい ほど凸起の頂角が小さく，ピッチは大きくなっている。

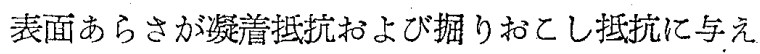
る影響についてその傾向をのべたが，第 2，3，4 困に つて摩㬗特性によ゙のように示されているか范みるて とにしよう.

銅/軟鋼板に扣いて, 前迹の考察によれば疑着担抗仿 ほぼ一定加面のあらいほど減少し，掘り枕しし抵抗(む しろ印削担抗といった方がよいかもしれない）は面の あらいほど增加する。第2図であらさAに扔いては摩 擦抵抗の大部分は凝着抵抗之考えてよく，加工方向に 直角に摩繁したときあらさC以上で面のあらいほど摩 摖か増加し,あらい面でAよりも著しく大きい摩擦を示 しているてとは，あらさの増大による掘り执てし抵抗 の増加加著しく大きいてとを示している．加工方向に 平行に摩擦したときは第1図のあらさのプロフイルか ら風り打しし抵抗の小さいととは予想され，乙れは摩

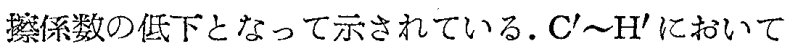
掘り机てし抵抗による摩擦增加はみられるが, $\mathrm{A}^{\prime}$ より

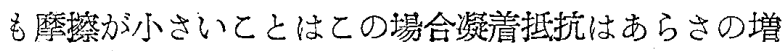
大とともに減少しているととを示しいてる，したがっ

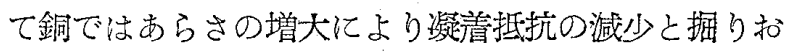
こし抵抗の增加を生している．すなわち加工方向に值 解に摩攃したときは，あらさの堌大による掘り和てし

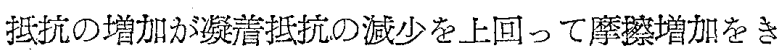


たし，平行方向に摩然したときは凝着挽 抗の減少の影響力゙大きい，掘り扔てし抵 抗の攀檫抵抗㑬寸る割合は, あらさ $\mathrm{C}^{\prime}$ で徒掘り扣とし抵抗が非常に小さいと考 えて $\mathrm{C}^{\prime}$ 汃らの増加を仮に求めれば，H で $30 \%, \mathrm{H}^{\prime}$ で15\%となる。凝請抵抗の 減少は $10 \%$ 内外となる。摩擦面のあら さの增大とともに摩摖加增大する特性は やわらかい金属供通して捛り，あらさ の增大による摩攃增加は掘り扣てし抵抗 の増加によるもので，たとえばすずでは
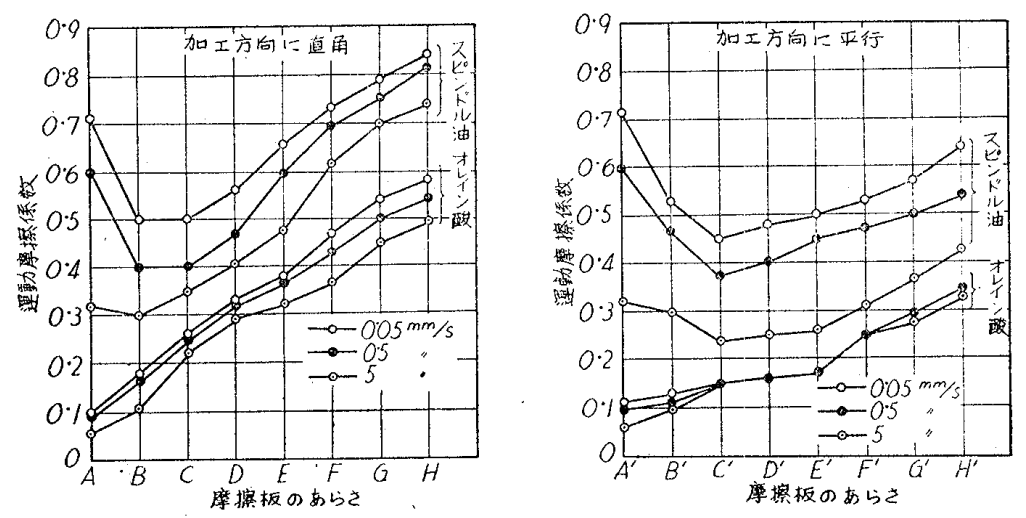

第 5 目 銅/軟鋏板

㠜着抵抗の変化が少なく据り扣てし担抗が $50 \%$ 以上 に当䇫するととがみられる。

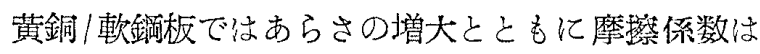
減少し，摩摖方向による摩擦の变化もみられない。摩 擦片金属がかたくなるにしたがって掘り打てし抵抗は 当然少なくなり，葨銅のいたみ方も銅にくらべて非常 代少なく，摩摖方间の影響がないととから掘り打てし 抵抗は非常に少ないと考えられる。あらさの増大によ

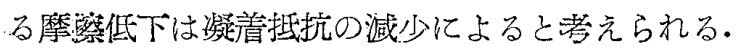

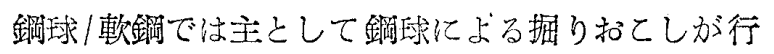
われる瑒合である.鋼球 (A) 亿ついて摩摖板のあらさ の増大によって摩漈の減少しているてとは，㠜青抵抗 の変化にさきに述べたようにあらさの增大とともに据 り打てし抵抗の減少する影曏が加わっているためであ

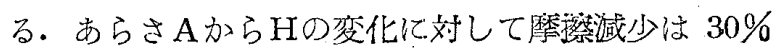
となっている。疾着提抗があらさに対して一定とすれ

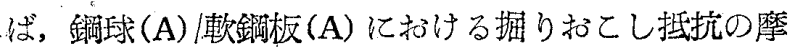

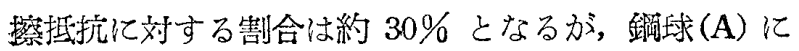

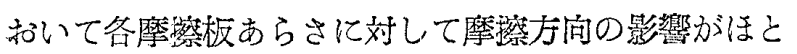
んぞなく，またさきに著者ら(15) が掘り执てし抵抗に ついて求めた結果では 10\% 以下となっているととか ら，凝着抵抗の減少の影響が大きい上うである。一定 のあらさの摩揳板に対して錒球のあらいぼ゙加工方向

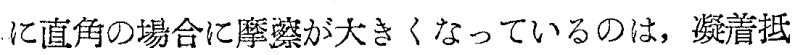
抗は減少する傾问にあるから掘り打てし抵抗の增加を 示して打り，加工方问に平䘕の埸合は掘り打てし抵抗 壮非常に少ないのは当然で銅球(A) とほぽ一致してい

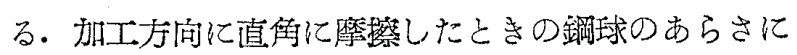

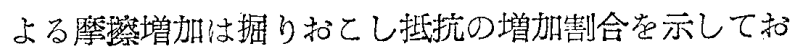
ク, ての割合は摩攃抵抗の $30 \%$ にも達している。

実験結果について要約すれで゚，乾燥摩擦に扔いて表

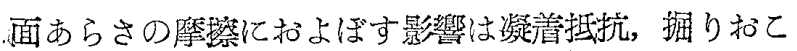
し抵扰のあらさによる変化としてあらわされ，あらさ の増大によって摩摖少增加するてとは，あらさによる 掘り打てし抵㹸の增加意瞅している。
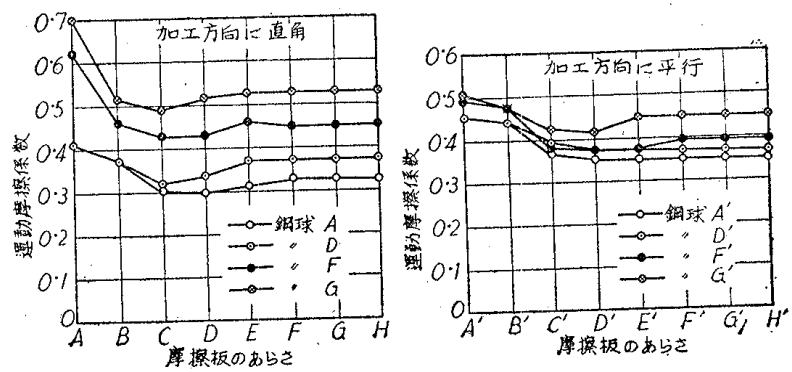

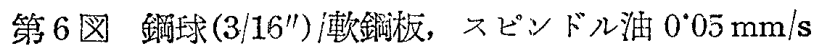
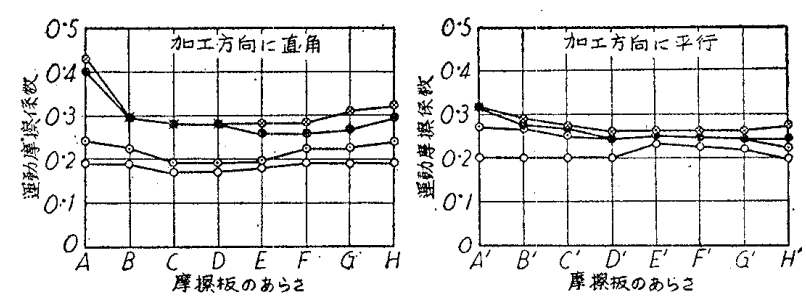

第 7 図 銅球 $\left(3 / 16^{\prime \prime}\right) /$ 軟鋼板, スピンドル淨 $5 \mathrm{~mm} / \mathrm{s}$
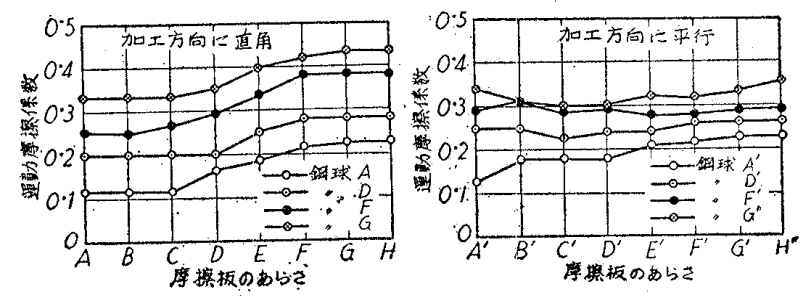

第 8 図 鋏球 $\left(3 / 16^{\prime \prime}\right)$ /軟鋼板, オレイン酸 $0.05 \mathrm{~mm} / \mathrm{s}$
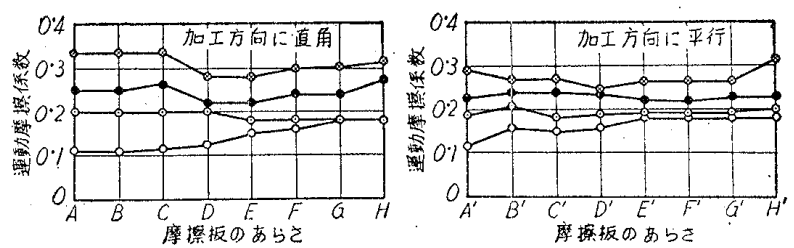

第 9 目 鋼球 $\left(3 / 16^{\prime \prime}\right)$ 潄鋏板, オレイン酸 $5 \mathrm{~mm} / \mathrm{s}$

\section{5. 境界潤滑に和ける表面あらさの影響}

スピンドル洋，オレイン酸の 2 種類について, 銅/軟

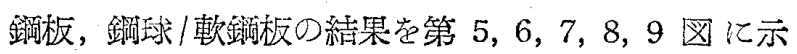
す. その特長的なととを簡単に述へよう。

銅/軟鋼板でスピンドル涌のずべり速度が低い上き 
は乾燥摩撜のときと同じ摩掽特性觉示している。これ

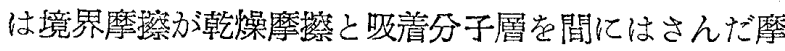

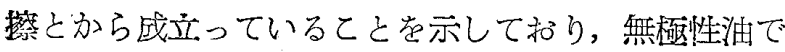
は大部分方乾燥摩䅎によって占められている。すべり 速度の増加による摩撜の低下は境界摩澄の特性で，摩 繁低下はあらさの小さいとてろで著しい。オレイン酸 ではあら゙さの增大とともに摩攃は一栐に増加してい

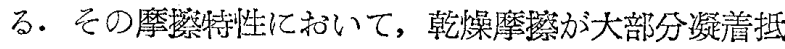
抗である領域では有䓧性の潤滑油は摩摖低下に大いに 役立つ方，切削抵抗が摩揞抵抗のかなりの割合を占め る領域に执いては，有極性の潤滑油を用いても潤滑効 果が非常に悪いととを示している．摩摖方向の影響と しては，加工方向に面有に摩擦したすが平行方向より

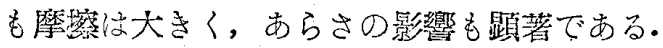

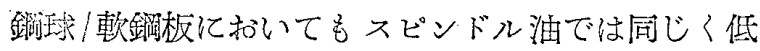
速度で颠燥摩擦に打けると同様な特性を示している。 すべり速度の大きいほどあらさの影響は少なくなって いる.オレイン酸に扣いては面のなめらかなはど摩㻮 は低く，すべり速度の影響はスピンドル洎と同様であ

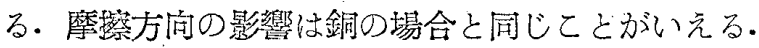

\section{6. む す び}

表面あらさと摩撜の主な関係について要衒すると (1) 凹凸を上下するための抵抗は，摩摖挰抗のごく 小部分にすぎない，摩穄抵扰の主なものは凝着抵抗で

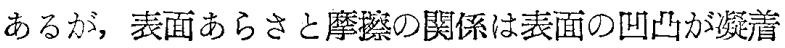
抗抵と掘り扎てし抵抗に与える影響によって説明され る.

（2）あらさの增大によって摩擦办増加するてとは掘 り打とし掑抗(切削提抗)の増加によるもので，やわら かい金属ほど著しい。

（3）摩擦方向の影響としては，加工方面に直角に摩 慗した方か社行方向よりも摩摖は大きく，あらさの影
響も顕著である.とくにやわらかい金属ではての影㗽 が藷しい。

境界潤滑における特長的なとととして

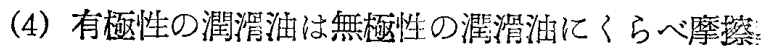
が低く，あらさの小さいほど差办著しい。

（5）一般にあらさの増大とともに摩擦は堌加する が，無極性潤渭油では面のなめらかなほど摩攃の堌加. することがみられる。

（6）かたい金属よりもやわらかい金属のときにあら さの影響が著しい，摩擦方向の影響は固体摩㻮に打り ると同じである.

（7）すべり速度の大きいほど摩摖は低くあらさの影 響があらわれにくい，各あらさにおいて無極性潤滑油 の方が極性潤渭油よりも速度増加による摩摖低下が大 きい.

本研究を行うに際して御指導をいただいた會田範宗 呚授にあつく打礼をもうしあげる次第である.

\section{交献}

(1) Hardy W.B., Collected Scientific Papers, London(1936)

(2) Holm R., Electric Contacts, Uppsala (1946) .

(3) Bowden F. P. \& Tabor D., The Friction and Lubrication of Solids, London (1950).

(4) Bristow J.R., Proc.Inst. Mech. Engg., Vol. 160, p. 384 (1949) .

(5) Whitehead J.R., Proc. Roy.Soc., [A], Vol. 201, p. 109 (1950).

(6) Strang C. D. \& Lewis C.R., J. Appl. Phys., Vol. 20, p. 1164 (1949).

(7) Bishop R.j.j., Hill R. \& Mott N. F., Proc. Phvs. Soc., Vol. 57, p. 147 (1945)

(8) Mcore J. W., Proc. Roy. Soc., [A], Vol. 195, p. 231 (1948) .

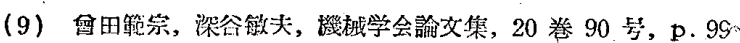
(1954) .

(10) 交献 (2)

(11) Bridgman P.W., Phys. Rev., Vol. 48, p. 825 (1935).

(12) Bridgman P.W., The Physics of High Pressure, 410 London (1949) .

(13) 女献 (2).

(14) 交祇 (3) .

（15）曾田範宗，宫川行雄，深谷锥夫，未発表。 